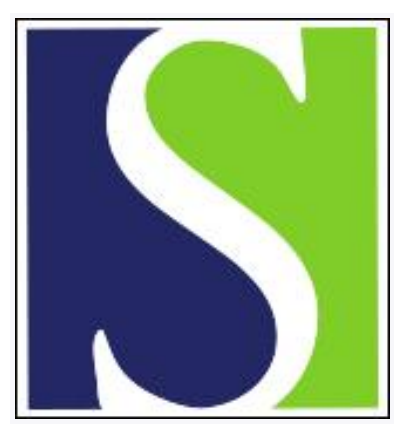

Scand J Work Environ Health 1985;11(6):397-407

https://doi.org/10.5271/sjweh.2208

Issue date: Dec 1985

\title{
Cancer among farmers. A review.
}

by Blair A, Malker H, Cantor KP, Burmeister L, Wiklund K

This article in PubMed: www.ncbi.nlm.nih.gov/pubmed/3912986

\section{(c) (1)}




\title{
Cancer among farmers
}

\section{A review}

\author{
by Aaron Blair, PhD, ${ }^{1}$ Hans Malker, MS, ${ }^{2}$ Kenneth $\mathrm{P}$ Cantor, $\mathrm{PhD},{ }^{1}$ Leon Burmeister, $\mathrm{PhD},{ }^{3}$ \\ Kerstin Wiklund, $\mathrm{MS}^{4}$
}

\begin{abstract}
BLAIR A, MALKER H, CANTOR KP, BURMEISTER L, WIKLUND K. Cancer among farmers: A review. Scand J Work Environ Health 11 (1985) 397-407. During the performance of routine tasks farmers may come in contact with a variety of substances, including pesticides, solvents, oils and fuels, dusts, paints, welding fumes, zoonotic viruses, microbes, and fungi. Because some of these substances are known or suspected carcinogens, the epidemiologic literature regarding cancer risks concerning farmers has been reviewed. Farmers had consistent deficits for cancers of the colon, rectum, liver, and nose. The deficits for cancer of the lung and bladder were particularly striking, presumably due to less frequent use of tobacco among farmers than among people in many other occupational groups. Malignancies frequently showing excesses among farmers included Hodgkin's disease, leukemia, non-Hodgkin's lymphoma, multiple myeloma, and cancers of the lip, stomach, prostate, skin (nonmelanotic), brain, and connective tissues. The etiologic factors that may contribute to these excesses in the agricultural environment have not been identified. Detailed, analytic epidemiologic studies that incorporate environmental and biochemical monitoring are needed to clarify these associations.
\end{abstract}

Key terms: analytic epidemiology.

Farming is a physically demanding occupation that requires varied skills. Farmers routinely perform tasks normally associated with other occupations; for example, they repair machinery, weld, apply pesticides, paint, and operate heavy equipment. In doing so, farmers may come in contact with a number of potentially hazardous chemical and biological agents, including pesticides, solvents, fuels and oils, dusts, zoonotic viruses, microbes, and fungi (58), some of which are known or suspected carcinogens. In addition the use of power tools and mechanized equipment and the tending of livestock place farmers at increased risk of accidental death or injury $(15,53,68)$.

Despite these potential hazards, overall mortality among farmers is less than that among the general population $(38,43,63)$ and many other occupations, including some white-collar groups. Lower mortality rates for ischemic heart disease among farmers than among other occupational groups have been reported from England and Wales (38), Australia (63), and the United States at the national (43), county (21), and state (74) level. Despite low mortality from all causes combined, surveys of occupational groups and studies

1 Environmental Epidemiology Branch, National Cancer Institute, Bethesda, Maryland, United States.

2 National Board of Occupational Safety and Health, S-171 84 Solna, Stockholm, Sweden.

3 Department of Preventive Medicine and Environmental Health, University of Iowa, Iowa City, Iowa 52242, United States.

4 Cancer Epidemiology Department, Karolinska Hospital, Solna, Sweden.

Reprint requests to: Dr A Blair, Environmental Epidemiology Branch, National Cancer Institute, Landow Building, Room 4C16, Bethesda, MD 20892, USA. of specific tumors suggest that farmers may have elevated incidence and mortality rates for certain cancers. A thorough review of the epidemiologic literature may help focus attention on agricultural factors that pose a carcinogenic risk to farmers. Some findings are also relevant to the general public, since many chemicals used by farmers (eg, insecticides, herbicides, paints, and solvents) are also used by other segments of the population.

\section{Materials and methods}

We have assembled findings from epidemiologic studies and broad occupational surveys of cancer mortality and morbidity among farmers from industrialized countries around the world. Table 1 details the occupational surveys included in this review, while tables $2-5$ present observed and expected numbers and ratios from these surveys by cause. The statistical significance of the ratios of the observed and expected numbers in tables 2-5 was assessed with the use of the ratio of a Poisson variable to its expectation following the procedure of Bailar \& Ederer (4). In order to summarize data from broad occupational surveys, we have grouped the cancers into three categories according to their pattern of risk among these populations. Cancers that occur among farmers more frequently than expected (risk ratios $>1.0$ ) in at least two-thirds of the surveys are in the high-risk category, while those that are not elevated or elevated in less than one-third of the surveys are in the low-risk category. The remaining cancer sites with elevated risks among farmers in more than one-third but less than two-thirds of the studies form the intermediate category. 
Table 1. Description of the occupational mortality and morbidity studies surveyed.

\begin{tabular}{|c|c|c|c|c|c|c|c|c|}
\hline $\begin{array}{l}\text { Geographic } \\
\text { location } \\
\text { of study }\end{array}$ & Data base & Years & $\begin{array}{l}\text { Total } \\
\text { number } \\
\text { of white } \\
\text { male } \\
\text { subjects }\end{array}$ & $\begin{array}{c}\text { Number of } \\
\text { malignant } \\
\text { neoplasms } \\
\text { among } \\
\text { farmers }\end{array}$ & $\begin{array}{l}\text { Age } \\
\text { range } \\
\text { (years) }\end{array}$ & $\begin{array}{l}\text { Mortality/ } \\
\text { incidence } \\
\text { index }\end{array}$ & Occupation & Reference \\
\hline $\begin{array}{l}\text { United States, } \\
\text { Washington } \\
\text { State }\end{array}$ & $\begin{array}{l}\text { Death } \\
\text { certificates }\end{array}$ & $1950-1979$ & 429926 & 4654 & $\geq 20$ & PMR & Usual & Milham (65) \\
\hline $\begin{array}{l}\text { United States, } \\
\text { California }\end{array}$ & $\begin{array}{l}\text { Death } \\
\text { certificates }\end{array}$ & $1951-1961$ & 200000 & 1956 & $\geq 20$ & PMR & Latest & $\begin{array}{l}\text { Petersen \& } \\
\text { Milham (73) }\end{array}$ \\
\hline $\begin{array}{l}\text { The Nether- } \\
\text { lands }\end{array}$ & $\begin{array}{l}\text { Death } \\
\text { certificates }\end{array}$ & $1931-1935$ & 23318 & 2801 & $\begin{array}{l}\text { All } \\
\text { ages }\end{array}$ & PMR & $\begin{array}{l}\text { Latest and } \\
\text { previous }\end{array}$ & Versluys (89) \\
\hline \multirow[t]{2}{*}{$\begin{array}{l}\text { United States, } \\
\text { lowa }\end{array}$} & $\begin{array}{l}\text { Death } \\
\text { certificates } \\
\text { and census }\end{array}$ & $1971-1978$ & $\begin{array}{l}\text { All white } \\
\text { men }\end{array}$ & $\begin{array}{l}\text { Not } \\
\text { given }\end{array}$ & $20-64$ & SMR & Usual & Pomrehn et al (74) \\
\hline & $\begin{array}{l}\text { Death } \\
\text { certificates }\end{array}$ & $1971-1978$ & 121101 & 6402 & $\geq 20$ & PMR & Usual & Burmeister (16) \\
\hline United States & $\begin{array}{l}\text { Death } \\
\text { certificates } \\
\text { and census }\end{array}$ & 1950 & $\begin{array}{l}\text { All white } \\
\text { men }\end{array}$ & 5165 & $20-64$ & SMR & Usual & Guralnick (43) \\
\hline $\begin{array}{l}\text { United States, } \\
\text { veterans }\end{array}$ & $\begin{array}{l}\text { Veterans with } \\
\text { life insurance }\end{array}$ & $1954-1970$ & 293458 & 824 & $31-84$ & SMR & Usual & Walrath et al $(90)$ \\
\hline $\begin{array}{l}\text { England and } \\
\text { Wales }\end{array}$ & $\begin{array}{l}\text { Death } \\
\text { certificates } \\
\text { and census }\end{array}$ & $1970-1972$ & 550297 & $\begin{array}{l}\text { Not } \\
\text { given }\end{array}$ & $15-64$ & SMR & Latest & $\begin{array}{l}\text { Fox \& Goldblatt } \\
\text { (38) }\end{array}$ \\
\hline Canada & $\begin{array}{l}10 \% \text { census } \\
\text { sample }\end{array}$ & $1965-1969$ & 415201 & 75 & $\begin{array}{l}\text { All } \\
\text { ages }\end{array}$ & SMR & Current & $\begin{array}{l}\text { Howe \& Lindsay } \\
\text { (51) }\end{array}$ \\
\hline Australia & $\begin{array}{l}\text { Death } \\
\text { certificates } \\
\text { and census }\end{array}$ & $1968-1978$ & All men & $\begin{array}{l}\text { Not } \\
\text { given }\end{array}$ & $30-64$ & SRR & Usual & $\begin{array}{l}\text { McMichael \& } \\
\text { Hartshorne (63) }\end{array}$ \\
\hline Denmark & $\begin{array}{l}\text { Death } \\
\text { certificates } \\
\text { and census }\end{array}$ & $1970-1975$ & 1401967 & 1012 & $\begin{array}{l}20-64 \\
(1970)\end{array}$ & SMR & $\begin{array}{l}\text { At census } \\
(1970)\end{array}$ & $\begin{array}{l}\text { Danmarks Statistik } \\
\text { (25) }\end{array}$ \\
\hline Sweden ${ }^{b}$ & $\begin{array}{l}\text { Death } \\
\text { certificates } \\
\text { and census }\end{array}$ & $1961-1970$ & 3738861 & 6593 & $\begin{array}{l}\geq 15 \\
(1960)\end{array}$ & SMR & $\begin{array}{l}\text { At census } \\
(1960)\end{array}$ & . \\
\hline $\begin{array}{l}\text { United States, } \\
\text { Massachusetts }\end{array}$ & $\begin{array}{l}\text { Death } \\
\text { certificates }\end{array}$ & $1971-1973$ & 34879 & 183 & $\geq 20$ & MOR & Usual & $\begin{array}{l}\text { Dubow \& Wegman } \\
\text { (30) }\end{array}$ \\
\hline Swedenc & $\begin{array}{l}\text { National } \\
\text { Swedish } \\
\text { Cancer- } \\
\text { Environment } \\
\text { Register }\end{array}$ & $1961-1979$ & 3738861 & 28226 & $\begin{array}{l}\geq 15 \\
(1960)\end{array}$ & SIR & $\begin{array}{l}\text { At census } \\
(1960)\end{array}$ & . \\
\hline $\begin{array}{l}\text { United States, } \\
\text { Roswell Park }\end{array}$ & $\begin{array}{l}\text { Hospital } \\
\text { register }\end{array}$ & $1956-1965$ & $\begin{array}{l}\quad 6434 \\
+ \text { unknown } \\
\text { number of } \\
\text { referents }\end{array}$ & 275 & $\geq 15$ & OR & $\begin{array}{l}\text { Lifetime } \\
\text { occupational } \\
\text { history }\end{array}$ & Decoufle et al (26) \\
\hline $\begin{array}{l}\text { United States, } \\
\text { Third National } \\
\text { Cancer Survey }\end{array}$ & $\begin{array}{l}10 \% \text { interview } \\
\text { survey of all } \\
\text { incident } \\
\text { cancer cases }\end{array}$ & $1969-1971$ & 3539 & 109 & $\geq 15$ & OR & Usual & $\begin{array}{l}\text { Williams et al } \\
(94)\end{array}$ \\
\hline $\begin{array}{l}\text { British } \\
\text { Columbia }\end{array}$ & $\begin{array}{l}\text { Death } \\
\text { certificates }\end{array}$ & $1950-1978$ & 254901 & 4602 & $\geq 20$ & PMR & Usual & $\begin{array}{l}\text { Gallagher et al } \\
\text { (39) }\end{array}$ \\
\hline
\end{tabular}

a $\mathrm{PMR}=$ proportionate mortality ratio, $\mathrm{SMR}=$ standardized mortality ratio, SRR = standardized risk ratio, MOR = mortality odds ratio, SIR = standardized incidence ratio, OR = odds ratio.

b Data from the linked register between the Death Cause Register (1961-1970) and the census of 1960 (82).

c Data from the linked register between the National Swedish Cancer Register (1961-1979) and the census of 1960 (93).

\section{Results}

Tables 2-6 display the risks for selected diseases among farmers from various countries. The studies are grouped according to design (ie, proportionate mortality, cohort, or case-referent). Although risks vary from population to population, certain patterns occur.

Mortality from all causes, arteriosclerotic heart disease, and all cancer is low among farmers. Specific cancers that fall into the low-risk category for farmers include those of the colon, rectum, liver, nose, lung, and bladder. Each survey showed a deficit for cancers of the lung and bladder, presumably due to the less frequent use of tobacco by farmers than by other occupational groups $(21,63,84,85)$. In Sweden, for example, in the early 1960 s about $30 \%$ of farmers smoked in comparison to nearly $50 \%$ of the general population (22). These figures would imply a relative risk of about 0.6 for lung cancer among farmers, on the assumption of a 10-fold relative risk for smoking (3). The consistent deficits for cancers of the colon 
may be related to high levels of physical activity among farmers (40). Reasons for the low risk of cancers of the rectum, liver, and nose are not clear.

Malignancies commonly high among farmers include Hodgkin's disease, multiple myeloma, and cancers of the lip, stomach, prostate, skin (nonmelanotic), brain and connective tissue. The remaining cancers [ie, nonHodgkin's lymphoma, leukemia, and cancers of the skin (melanoma), esophagus, pancreas, testis and kidney] show a generally inconsistent pattern. Leukemia, non-Hodgkin's lymphoma, and cancers of the skin (melanoma) and pancreas show relative risks greater than 1 in more than $50 \%$ of the surveys.

The observed numbers of specific cancers were small in a few surveys, and cancers with fewer than three cases or deaths were dropped from consideration in table 6. Despite this restriction, the risk pattern in table 6 is nearly identical to that in tables $2-5$. Cancers commonly high among farmers (ie, elevated risk in two-thirds of the eligible surveys) in the restricted evaluation included Hodgkin's disease, multiple myeloma, leukemia, and cancers of the lip, stomach, prostate, skin (nonmelanotic), brain and connective tissue. The relative risks for these sites were usually less than 1.5, except for cancer of the lip, for which five of six studies had relative risks greater than 1.5.
For the other cancers in the commonly high category, the proportion of the studies with relative risks less than 1.1 was $8 \%$ for stomach, $33 \%$ for prostate, $20 \%$ for nonmelanotic skin, $38 \%$ for brain, and $20 \%$ for connective tissue cancer and $33 \%$ for Hodgkin's disease, $17 \%$ for multiple myeloma, and $22 \%$ for leukemia. Sites generally not elevated in this restricted set of studies included cancer of the esophagus, colon, rectum, liver, nose, lung, and bladder.

The risks among farmers are not exceptionally high for most cancers, and many elevations did.not achieve statistical significance. The proportion of studies reported in table 6 with statistically significant elevations in relative risks by specific cancer was lip (43\%), stomach $(58 \%)$, prostate $(33 \%)$, skin $(40 \%)$, brain $(0 \%)$, connective tissue $(0 \%)$, Hodgkin's disease $(0 \%)$, multiple myeloma (43\%), and leukemia (22 \%). The consistent excesses for specific cancers across these broad surveys prompted us to conduct a detailed review of the literature for further information on the sites of particular interest, ie, those in the commonly high category.

\section{Leukemia}

Of studies investigating the association between farming and cancer, leukemia has received the most attention.

Table 2. Mortality from all causes, heart disease, and cancer among farmers from various countries.

\begin{tabular}{|c|c|c|c|c|c|c|}
\hline \multirow{2}{*}{ Country ${ }^{a}$} & \multicolumn{2}{|c|}{ All causes } & \multicolumn{2}{|c|}{$\begin{array}{l}\text { Arteriosclerotic } \\
\text { heart disease }\end{array}$} & \multicolumn{2}{|c|}{ All cancer } \\
\hline & $N^{b}$ & Risk & $N^{b}$ & Risk & $N^{0}$ & Risk \\
\hline \multicolumn{7}{|c|}{ I. $\quad$ Proportionate mortality ratios (risk $=P M R$ ) } \\
\hline United States, Washington (65) & $\ldots$ & . & 11315 & $0.98^{*}$ & 4654 & $0.95^{*}$ \\
\hline United States, California (73) & $\ldots$ & $\cdots$ & 4792 & 1.00 & 1956 & 0.98 \\
\hline United States, lowa (16) & .. & .. & . & .. & 6402 & $0.97^{\star}$ \\
\hline The Netherlands (89) & .. & . & & & 2801 & 1.00 \\
\hline British Columbia (39) & . & $\therefore$ & 11100 & 1.01 & 4602 & $0.94^{*}$ \\
\hline \multicolumn{7}{|c|}{ II. Standardized mortality ratio (risk $=S M R$ ) } \\
\hline United States (43) & 36273 & $0.83^{*}$ & 8648 & $0.69^{\star}$ & 5165 & $0.77^{*}$ \\
\hline United States, veterans (90) & 4489 & $0.92^{*}$ & 1797 & $0.91^{*}$ & 824 & $0.90^{*}$ \\
\hline United States, lowa (74) & & $0.93^{*}$ & & $0.92^{*}$ & $\cdots$ & $0.89^{*}$ \\
\hline England and Wales ${ }^{\circ}(38)$ & 10041 & $0.91^{*}$ & $\cdots$ & 0.82 & $\cdots$ & 0.92 \\
\hline Canada (51) & 331 & $0.88^{\star}$ & & & & 0.87 \\
\hline Denmark (25) & 3283 & $0.67^{\star}$ & 1087 & $0.68^{\star}$ & 1012 & $0.67^{*}$ \\
\hline Australia (63) & & $0.90^{*}$ & & $0.86^{*}$ & & \\
\hline Sweden (82) & 32151 & $0.82^{*}$ & 10252 & $0.78^{*}$ & 6593 & $0.85^{*}$ \\
\hline \multicolumn{7}{|c|}{ III. Standardized incidence ratios (risk $=S I R$ ) } \\
\hline Sweden (93) & - & . & $\cdots$ & . & 28205 & $0.92^{*}$ \\
\hline \multicolumn{7}{|c|}{ IV. Case-referent studies (risk $=$ odds ratio) } \\
\hline $\begin{array}{l}\text { United States, Roswell Park (26) } \\
\text { United States, Third National }\end{array}$ & $\cdots$ & $\cdots$ & $\cdots$ & . & $\cdots$ & . \\
\hline Cancer Survey (94) & .. & $\ldots$ & .. & $\ldots$ & & \\
\hline United States, Massachusetts ${ }^{d}(30)$ & . & . & .. & $\therefore$ & 181 & $0.78^{*}$ \\
\hline \multicolumn{7}{|l|}{$\begin{array}{l}\text { Percentage of surveys showing excess } \\
\text { (with number excessive/total }\end{array}$} \\
\hline $\begin{array}{l}\text { in parentheses) } \\
\text { Risk categorye }\end{array}$ & \multicolumn{2}{|c|}{0 Low } & \multicolumn{2}{|c|}{10 Low } & \multicolumn{2}{|c|}{0 Low } \\
\hline
\end{tabular}

a Reference in parentheses.

b For the proportionate and standardized mortality ratios $N$ = number of deaths among the farmers; for the case-referent studies $\mathrm{N}=$ number of farmers among the cases.

c Farmers, foresters, and fishermen.

d Risk determined from the mortality odds ratio.

Low = cancer occurrence not elevated or elevated in less than one-third of the surveys.

${ }^{*} \mathrm{p} \leq 0.05$. 
Table 3. Risk of cancer of the lip, esophagus, stomach, colon, rectum, liver, and pancreas among farmers from various countries. (Numbers and risks connected with a broken line are figures for the included group of cancer sites)

\begin{tabular}{|c|c|c|c|c|c|c|c|c|c|c|c|c|c|c|}
\hline \multirow{3}{*}{ Country ${ }^{\text {a }}$} & \multicolumn{14}{|c|}{ Cancer sites } \\
\hline & \multicolumn{2}{|c|}{ Lip } & \multicolumn{2}{|c|}{ Esophagus } & \multicolumn{2}{|c|}{ Stomach } & \multicolumn{2}{|c|}{ Colon } & \multicolumn{2}{|c|}{ Rectum } & \multicolumn{2}{|c|}{ Liver } & \multicolumn{2}{|c|}{ Pancreas } \\
\hline & $\mathrm{Nb}$ & Risk & $N^{b}$ & Risk & $\mathrm{N}^{\mathrm{b}}$ & Risk & $\mathrm{N}^{\mathrm{b}}$ & Risk & $\mathrm{N}^{\mathrm{b}}$ & Risk & $\mathrm{Nb}$ & Risk & $\mathrm{Nb}$ & Risk \\
\hline \multicolumn{15}{|c|}{ I. Proportionate mortality ratios (risk $=P M R$ ) } \\
\hline $\begin{array}{l}\text { United States, Washington (65) } \\
\text { United States, California (73) } \\
\text { United States, lowa (16) } \\
\text { The Netherlands (89) } \\
\text { British Columbia (39) }\end{array}$ & $\begin{array}{r}21 \\
3 \\
20 \\
25 \\
17\end{array}$ & $\begin{array}{l}1.56 \\
1.30 \\
1.62 \\
1.87^{*} \\
1.91^{\star}\end{array}$ & $\begin{array}{r}82 \\
55 \\
95 \\
171 \\
68\end{array}$ & $\begin{array}{l}0.83 \\
1.23 \\
0.74^{\star} \\
0.92 \\
0.59^{\star}\end{array}$ & $\begin{array}{r}573 \\
210 \\
338 \\
1566 \\
672\end{array}$ & $\begin{array}{l}1.18^{*} \\
1.12 \\
1.14^{\star} \\
1.23^{\star} \\
1.19^{\star}\end{array}$ & $\begin{array}{r}428 \\
188 \\
1064 \\
163 \\
389\end{array}$ & $\begin{array}{l}0.88^{\star} \\
0.98^{*} \\
0.78^{*} \\
0.84^{*}\end{array}$ & $\begin{array}{c}203 \\
93 \\
166 \\
\cdots\end{array}$ & $\begin{array}{r}0.94 \\
0.92 \\
-1.03 \\
0.90 \\
\ldots\end{array}$ & $\begin{array}{r}91 \\
13 \\
54 \\
159 \\
\cdots\end{array}$ & $\begin{array}{c}1.02 \\
0.77 \\
0.90 \\
1.06 \\
\ldots\end{array}$ & $\begin{array}{r}323 \\
139 \\
416 \\
17 \\
334\end{array}$ & $\begin{array}{l}1.09 \\
1.17 \\
1.07 \\
0.52^{*} \\
1.05\end{array}$ \\
\hline \multicolumn{15}{|c|}{ II. Standardized mortality ratio (risk $=S M R)$} \\
\hline $\begin{array}{l}\text { United States (43) } \\
\text { United States, veterans (90) } \\
\text { England and Wales }{ }^{\circ}(38) \\
\text { Canada (51) }\end{array}$ & $\begin{array}{l}\cdots \\
\cdots \\
\cdots\end{array}$ & $\begin{array}{l}\cdots \\
\cdots \\
\cdots\end{array}$ & $\begin{array}{r}\ddot{9} \\
\ddot{2}\end{array}$ & $\begin{array}{l}0 . \dot{6} \dot{1} \\
1.13 \\
1.10\end{array}$ & $\begin{array}{r}763 \\
60 \\
15\end{array}$ & $\begin{array}{l}0.89^{*} \\
1.07 \\
0.97 \\
1.77\end{array}$ & $\begin{array}{r}647 \\
87 \\
\because \\
4\end{array}$ & $\begin{array}{l}0.71^{*} \\
1.20 \\
0.53\end{array}$ & 32 & $\begin{array}{r}0.69 \\
0.79 \\
1.00 \\
1.16\end{array}$ & $\begin{array}{l}\ddot{19} \\
\ddot{\cdots}\end{array}$ & $\begin{array}{c}0.83 \\
\ldots \\
\ldots\end{array}$ & $\begin{array}{l}60 \\
\ddot{3}\end{array}$ & $\begin{array}{l}1.03 \\
1.02 \\
0.57\end{array}$ \\
\hline $\begin{array}{l}\text { Denmark (25) } \\
\text { Australia (63) } \\
\text { Sweden (82) }\end{array}$ & $\begin{array}{r}343 \\
\ddot{9}\end{array}$ & 1.9 & $\ddot{8} \dot{7}$ & $0 . \ddot{6} \dot{1}$ & $160 \ddot{1}$ & $\begin{array}{l}0.96 \\
1.08^{*}\end{array}$ & $4 \ddot{5} \dot{9}$ & $\begin{array}{l}0.81 * \\
0.74^{*}\end{array}$ & $3 \ddot{8}$ & $\begin{array}{l}0.84 * \\
0.90\end{array}$ & $\ddot{30}$ & $0.50^{*}$ & $4 \ddot{6} \dot{4}$ & $\begin{array}{l}0.72^{\star} \\
0.91 \\
0.80^{*}\end{array}$ \\
\hline \multicolumn{15}{|c|}{ III. Standardized incidence ratio (risk $=S I R)$} \\
\hline Sweden (93) & 777 & $1.63^{*}$ & 246 & $0.71^{*}$ & 3399 & $1.10^{*}$ & 1850 & $0.80^{*}$ & 1624 & 0.96 & 411 & $0.61^{*}$ & 1021 & $0.88^{*}$ \\
\hline \multicolumn{15}{|c|}{ IV. Case-referent studies (risk $=$ odds ratio) } \\
\hline $\begin{array}{l}\text { United States, Roswell Park (26) } \\
\text { United States, Third National }\end{array}$ & . & $\cdots$ & 6 & 1.00 & 22 & $1.67^{*}$ & 33 - & (n........ & (n............ & $-0.58^{*}$ & $\cdots$ & $\cdots$ & $\cdots$ & . \\
\hline $\begin{array}{l}\text { Cancer Survey (94) } \\
\text { United States, Massachusetts d }(30)\end{array}$ & $\begin{array}{l}\cdots \\
\cdots\end{array}$ & $\begin{array}{l}\cdots \\
\cdots\end{array}$ & $\begin{array}{l}2 \\
\cdots\end{array}$ & $\begin{array}{ll}1.03 \\
\ldots\end{array}$ & $\begin{array}{c}4 \\
-6\end{array}$ & $\begin{array}{r}0.49 \\
\ldots\end{array}$ & $\begin{array}{r}15 \\
7\end{array}$ & $\begin{array}{l}1.24 \\
2.33\end{array}$ & $\begin{array}{l}6 \\
\cdots\end{array}$ & $\begin{array}{r}0.77 \\
\ldots\end{array}$ & $\cdots$ & $\begin{array}{l}\cdots \\
\cdots\end{array}$ & $\begin{array}{l}5 \\
5\end{array}$ & $\begin{array}{l}1.05 \\
1.37\end{array}$ \\
\hline $\begin{array}{l}\text { Percentage of surveys showing } \\
\text { an excess (with number } \\
\text { excessive/total in parentheses) } \\
\text { Risk category }\end{array}$ & ${ }^{100}$ & $\begin{array}{ll}(7 / 7) \\
g h\end{array}$ & $\begin{array}{l}33 \\
\text { Interm }\end{array}$ & $\begin{array}{c}(4 / 12) \\
\text { nediate }\end{array}$ & 71 Hic & igh & 25 Lo & $\begin{array}{l}(3 / 12) \\
\text { ow }\end{array}$ & ${ }^{10}$ Lo & $\begin{array}{l}(1 / 10) \\
\text { ow }\end{array}$ & & ow & Interm & $\begin{array}{l}(8 / 14) \\
\text { nediate }\end{array}$ \\
\hline
\end{tabular}

a Reference number in parentheses.

- For the proportionate and standardized mortality ratios $N=$ number of deaths among the farmers; for the case-referent studies $\mathrm{N}=$ number of farmers among the cases.

c Farmers, foresters, and fishermen.

d Risk determined from the mortality odds ratio.

- Does not include a study if the figures given are for a group of sites.

1 High = cancer occurrence more frequent among farmers than expected (risk ratio $>1.0$ ) in at least two-thirds of the surveys, low $=$ cancer occurrence not elevated or elevated in less than one-third of the surveys, intermediate = cancer occurrence elevated in more than one-third but less than two-thirds of the studies.

* $p \leq 0.05$.

Studies in the United States from Washington (64), California (35), Nebraska $(10,12)$, Iowa $(18,28)$, Wisconsin (11), and Illinois (14), as well as from British Columbia (39) and Tasmania (41), suggest that farmers are at higher risk of leukemia than many other occupations. The study from Tasmania (41) also noted increased relative risks for myeloproliferative and lymphoproliferative disorders among persons employed in rural industries (not further described). Not all studies, however, have shown this association. An initial report on leukemia incidence in Olmsted County, Minnesota, suggesting that farmers were at high risk (61), was not confirmed in a more detailed, casereferent study (62).

Recent studies have attempted to identify specific agents or farm practices related to leukemia risk. In death-certificate case-referent studies $(10,11,18)$, the risk of leukemia was the greatest among farmers born after 1900 and/or dying before 65 years of age, a phenomenon suggesting that more recent agricultural practices may be associated with an increase in risk. A link with oncogenic viruses has also been suggested. This hypothesis is particularly appealing since an infectious virus has been established as the primary agent in bovine lymphoma and because human exposure may occur through contact with infected animals and/or from the use of unpasteurized milk (37). Although the virus can cross species barriers (47), there is no serologic evidence that it can be transmitted to humans $(29,80)$. Furthermore, findings from ecological comparisons between the distribution of cattle populations and the occurrence of human leukemia are inconsistent $(7,55$, $57,96)$. No such association was noted in geographic studies from Sweden (57), Russia (55), and the United States (7), nor did studies in Wisconsin (11) and New York (81) find evidence of increased risk among dairy farmers in comparison to that among other farmers. On the other hand, the frequency of bovine leukemia in areas in Poland (96) correlated positively with leukemia rates among humans, and Donham et al (28) found elevated rates of acute lymphatic leukemia among Iowa men from counties where dairying was an important agricultural activity. The rates for acute lymphatic leukemia were the highest among persons from Iowa counties where dairy herds were known to be infected with the bovine leukemia virus. Burmeister et al (18) also reported higher risks for unspecified lymphatic leukemia among Iowa farmers from dairying counties. In summary, despite some suggestive findings, the weight of serologic and epidemiologic evidence gives little support to a role for bovine leukemia viruses in the etiology of human leukemia.

Other zoonotic viruses, such as that involved in fowl leukosis, have been considered possible etiologic agents 
Table 4. Risk of melanotic and nonmelanotic skin cancers and cancer of the prostate, testis, kidney, bladder and brain among farmers from various countries. (Numbers and risks connected with a broken line are figures for the included group of cancer sites)

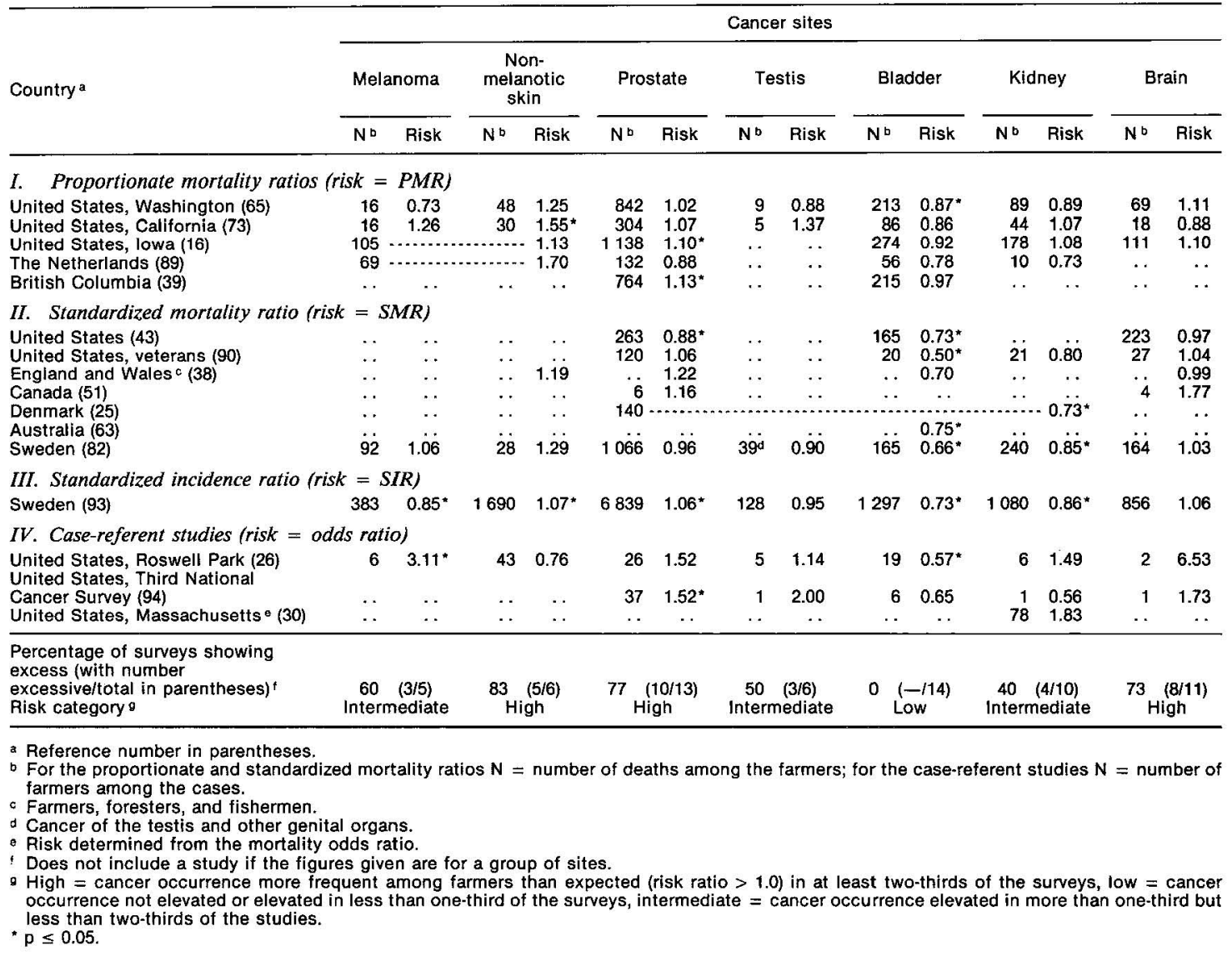

in human leukemia (47). The epidemiologic evidence to support this hypothesis is mixed. Milham (64) used death certificates from Washington and Oregon in a case-referent approach and reported a significantly elevated risk for leukemia and multiple myeloma among poultrymen, and unspecified lymphatic leukemia was elevated among Iowa farmers from counties with a large poultry industry (18). These reports suggest that oncogenic viruses (fowl leukosis) may be involved. Associations between leukemia and poultry production were not seen in other studies however $(10,75)$.

In several studies $(10,11,12,18)$ the subjects were stratified according to agricultural characteristics of their county of residence to uncover farm-related factors associated with the risk of leukemia. Although no single agricultural factor has been consistently associated with leukemia risk, correlations with insecticide use were noted in Nebraska $(10,12)$ and Wisconsin $(11)$, with herbicide use in lowa (18), and with corn production in Nebraska (10) and Iowa (18). Several studies have attempted to correlate specific histological types of leukemia with farm practices. Acute and chronic lymphatic and acute unspecified were the cell types most strongly associated with farming in Nebraska (10,
12) and Iowa $(18,28)$, while chronic myeloid leukemia showed the strongest association among Wisconsin farmers (11). In Iowa (18) unspecified lymphatic leukemia was elevated among farmers from heavy soybean-producing counties, while in Nebraska (12) acute lymphatic leukemia and acute and chronic myeloid leukemia were associated with corn production.

\section{Other lymphatic and hematopoietic cancers}

Other hematopoietic malignancies have not been as extensively studied as leukemia with regard to the role of agricultural factors. In California, farm residence was associated with leukemia mortality, but no association was found with non-Hodgkin's lymphoma, Hodgkin's disease, or multiple myeloma (35).

Cantor (19), using a death-certificate case-referent approach similar to that employed in studies of leukemia $(10,11,18)$, found that Wisconsin farmers from heavy fertilizer-, herbicide-, and insecticideusing counties had increased risks of non-Hodgkin's lymphoma. The association between non-Hodgkin's lymphoma and farming in Wisconsin was stronger 
Table 5. Risk of cancer of the nose, lung, and connective tissue and of non-Hodgkin's lymphoma, Hodgkin's disease, multiple myeloma, and leukemia among farmers from various countries. (Numbers and risks connected with a broken line are figures for the included group cancer sites)

\begin{tabular}{|c|c|c|c|c|c|c|c|c|c|c|c|c|c|c|}
\hline \multirow{3}{*}{ Country ${ }^{a}$} & \multicolumn{14}{|c|}{ Cancer sites } \\
\hline & \multicolumn{2}{|c|}{ Nasal } & \multicolumn{2}{|c|}{ Lung } & \multicolumn{2}{|c|}{$\begin{array}{l}\text { Connective } \\
\text { tissue }\end{array}$} & \multicolumn{2}{|c|}{$\begin{array}{c}\text { Non- } \\
\text { Hodgkin's } \\
\text { lymphoma }\end{array}$} & \multicolumn{2}{|c|}{$\begin{array}{l}\text { Hodgkin's } \\
\text { disease }\end{array}$} & \multicolumn{2}{|c|}{$\begin{array}{l}\text { Multiple } \\
\text { myeloma }\end{array}$} & \multicolumn{2}{|c|}{ Leukemia } \\
\hline & $\mathrm{No}$ & Rișk & No & Risk & $\mathbf{N}^{\mathbf{b}}$ & Risk & $\mathrm{N}^{\mathrm{b}}$ & Risk & $\mathrm{N}^{\mathrm{b}}$ & Risk & $\mathrm{N}^{\mathrm{b}}$ & Risk & $\mathrm{N}^{\mathrm{b}}$ & Risk \\
\hline \multicolumn{15}{|c|}{ I. Proportionate mortality ratios (risk $=P M R$ ) } \\
\hline $\begin{array}{l}\text { United States, Washington (65) } \\
\text { United States, California (73) } \\
\text { United States, lowa (16) } \\
\text { The Netherlands (89) } \\
\text { British Columbia (39) }\end{array}$ & $\begin{array}{l}9 \\
\cdots \\
\cdots \\
14\end{array}$ & $\begin{array}{c}0.63 \\
\cdots \\
\cdots\end{array}$ & $\begin{array}{r}646 \\
167 \\
1466 \\
63 \\
742\end{array}$ & $\begin{array}{l}0.79^{*} \\
0.64^{*} \\
0.78^{*} \\
0.41^{*} \\
0.66^{*}\end{array}$ & $\begin{array}{c}25 \\
8 \\
56^{\mathrm{c}} \\
\cdots \\
\cdots\end{array}$ & $\begin{array}{c}1.52 \\
1.21 \\
1.08 \\
\quad \cdots \\
\cdots\end{array}$ & $\begin{array}{r}72 \\
36 \\
208\end{array}$ & $\begin{array}{l}1.01 \\
0.81 \\
1.14^{*}\end{array}$ & $\begin{array}{l}38 \\
20 \\
47 \\
\cdots\end{array}$ & $\begin{array}{r}1.07 \\
1.34 \\
1.22 \\
\quad . \\
\quad .\end{array}$ & $\begin{array}{r}78 \\
22 \\
133\end{array}$ & $\begin{array}{l}1.25 \\
1.00 \\
1.27^{\star}\end{array}$ & $\begin{array}{r}225 \\
97 \\
332\end{array}$ & $\begin{array}{l}1.07 \\
1.15 \\
1.10\end{array}$ \\
\hline \multicolumn{15}{|c|}{ II. Standardized mortality ratio (risk $=S M R$ ) } \\
\hline $\begin{array}{l}\text { United States (43) } \\
\text { United States, veterans (90) } \\
\text { England and Wales }{ }^{\mathrm{d}}(38) \\
\text { Canada (51) } \\
\text { Denmark (25) } \\
\text { Australia (63) } \\
\text { Sweden (82) }\end{array}$ & $\begin{array}{l}\cdots \\
\cdots \\
\cdots \\
\cdots\end{array}$ & & $\begin{array}{r}728 \\
144 \\
\dddot{19} \\
234\end{array}$ & $\begin{array}{l}0.55^{*} \\
0.83^{*} \\
0.84 \\
0.69 \\
0.44^{\star t} \\
0.73^{*} \\
0.45^{*}\end{array}$ & $\begin{array}{l}\because \\
\because \\
\because \\
\therefore\end{array}$ & $\begin{array}{l}\because \\
\because \\
\because \\
\cdots \\
\cdots\end{array}$ & $\begin{array}{c}348 \\
\cdots \\
\ddot{3} \\
.\end{array}$ & $\begin{array}{l}1.12^{\circ} \\
0.62 \\
\cdots\end{array}$ & $\begin{array}{r}348- \\
\because \\
\ddot{3} \\
128\end{array}$ & 1.03 & $\begin{array}{l}\cdots \\
\cdots \\
\cdots \\
\cdots \cdots\end{array}$ & $\begin{array}{c}0.89^{*} \\
\quad \cdots \\
0.62 \\
0.6\end{array}$ & $\begin{array}{r}333 \\
55 \\
\because \\
1 \\
\cdots\end{array}$ & $\begin{array}{l}1.16^{*} \\
1.13 \\
0.33 \\
1.03 \\
0.92\end{array}$ \\
\hline \multicolumn{14}{|c|}{ III. Standardized incidence ratio (risk $=$ SIR) } & 1.01 \\
\hline \multicolumn{15}{|c|}{ IV. Case-referent studies (risk $=$ odds ratio) } \\
\hline $\begin{array}{l}\text { United States, Roswell Park (26) } \\
\text { United States, Third National } \\
\text { Cancer Survey (94) } \\
\text { United States, Massachusetts } 9 \text { (30) }\end{array}$ & $\begin{array}{l}\cdots \\
5 \\
\cdots\end{array}$ & $\begin{array}{c}0.89 \\
. .\end{array}$ & $\begin{array}{l}51 \\
15\end{array}$ & $\begin{array}{l}0.69^{*} \\
0.79\end{array}$ & $\begin{array}{l}. \\
. .\end{array}$ & $\because$ & $\begin{array}{r}1 \\
. .\end{array}$ & $\begin{array}{c}2.15 \\
. .\end{array}$ & $\begin{array}{r}1 \\
. .\end{array}$ & $\begin{array}{r}1.50 \\
. .\end{array}$ & $\begin{array}{l}1 \\
7\end{array}$ & $\begin{array}{l}1.17 \\
3.09^{*}\end{array}$ & $\begin{array}{c}2 \\
. .\end{array}$ & $\begin{array}{r}0.56 \\
\ldots\end{array}$ \\
\hline $\begin{array}{l}\text { Percentage of surveys showing } \\
\text { excess (with number } \\
\text { excessiveltotal in parentheses) }^{\mathrm{h}} \\
\text { Risk category }^{\mathrm{i}}\end{array}$ & ${ }^{20} \mathrm{~L}$ & $\begin{array}{l}(1 / 5) \\
w\end{array}$ & 01 & $\begin{array}{l}(-115) \\
\text { ow }\end{array}$ & ${ }^{80} \mathrm{Hi}$ & & $\begin{array}{c}55 \\
\text { Interm }\end{array}$ & $\begin{array}{l}(6 / 11) \\
\text { lediate }\end{array}$ & & & & & $\begin{array}{c}64 \quad 17 \\
\text { Interme }\end{array}$ & $\begin{array}{l}\text { (7/11) } \\
\text { lediate }\end{array}$ \\
\hline \multicolumn{15}{|c|}{$\begin{array}{l}\text { Reference number in parentheses. } \\
\text { For the proportionate and standardized mortality ratios } N=\text { number of deaths among the farmers; for the case-referent studies } N=\text { number of } \\
\text { farmers among the cases. } \\
\text { c Connective tissue and bone cancer. } \\
\text { o Farmers, foresters, and fishermen. } \\
\text { a Lymphosarcoma only. } \\
\text { t Cancer of the respiratory system. } \\
\text { Risk determined from the mortality odds ratio. } \\
\text { h Does not include a study if the figures given are for a group of sites. } \\
\text { i High = cancer occurrence more frequent among farmers than expected (risk ratio }>1.0 \text { ) in at least two-thirds of the surveys, low }=\text { cancer } \\
\text { occurrence not elevated or elevated in less than one-third of the surveys, intermediate }=\text { cancer occurrence elevated in more than one-third but } \\
\text { less than two-thirds of the studies. } \\
\text { * } p \leq 0.05 \text {. }\end{array}$} \\
\hline
\end{tabular}

among decedents born more recently and among those less than 65 years of age than among those dying at older ages. Mortality from non-Hodgkin's lymphoma in New Zealand showed a similar age pattern (72). In Iowa, however, the risk of non-Hodgkin's lymphoma was greater among farmers born before 1890 or dying after age 65 (17) and among farmers residing in counties where herbicide usage was high and in counties where chickens, hogs, and dairy products were major commodities. Results from case-referent studies in Sweden are consistent with the association between herbicide use and non-Hodgkin's lymphoma in Iowa and Wisconsin. In the Swedish study herbicide exposure was associated with a fivefold risk of Hodgkin's disease and non-Hodgkin's lymphoma (45). Most herbicide exposures in the Swedish study were farmrelated. Prior to this report, Hodgkin's disease had not previously been linked to farming in general or to specific agricultural exposures (44).

Multiple myeloma has been associated with farming in Washington and Oregon (64), Wisconsin (20), Iowa (17), and Texas (1). In Wisconsin, farmers born before
1906 or dying after age 65 were at the highest risk (20), but no such pattern was discernable among lowa farmers (17). In New Zealand the risk of multiple myeloma was greater among farmers under 65 years of age (72). In Wisconsin and Iowa, however, farmers residing in counties with heavy herbicide and insecticide use or with large chicken inventories were at higher risk than farmers residing elsewhere. Particularly striking was the elevated risk among Wisconsin farmers from heavy insecticide-using counties who were born after 1906 . This was the only situation in the Wisconsin study where the relative risk for farmers born more recently was higher than those born earlier. Farmers born during this recent time period are more likely to have engaged in modern, chemical farming than farmers born earlier. In New Zealand (72) farmers in general were at higher risk of non-Hodgkin's lymphoma and multiple myeloma than other occupations. There was no association for dairy or other livestock farmers.

\section{Soft-tissue sarcomas}

Since many farmers use herbicides, Swedish reports 
Table 6. Surveys with three or more deaths or cases per cancer site among farmers. ${ }^{a}$

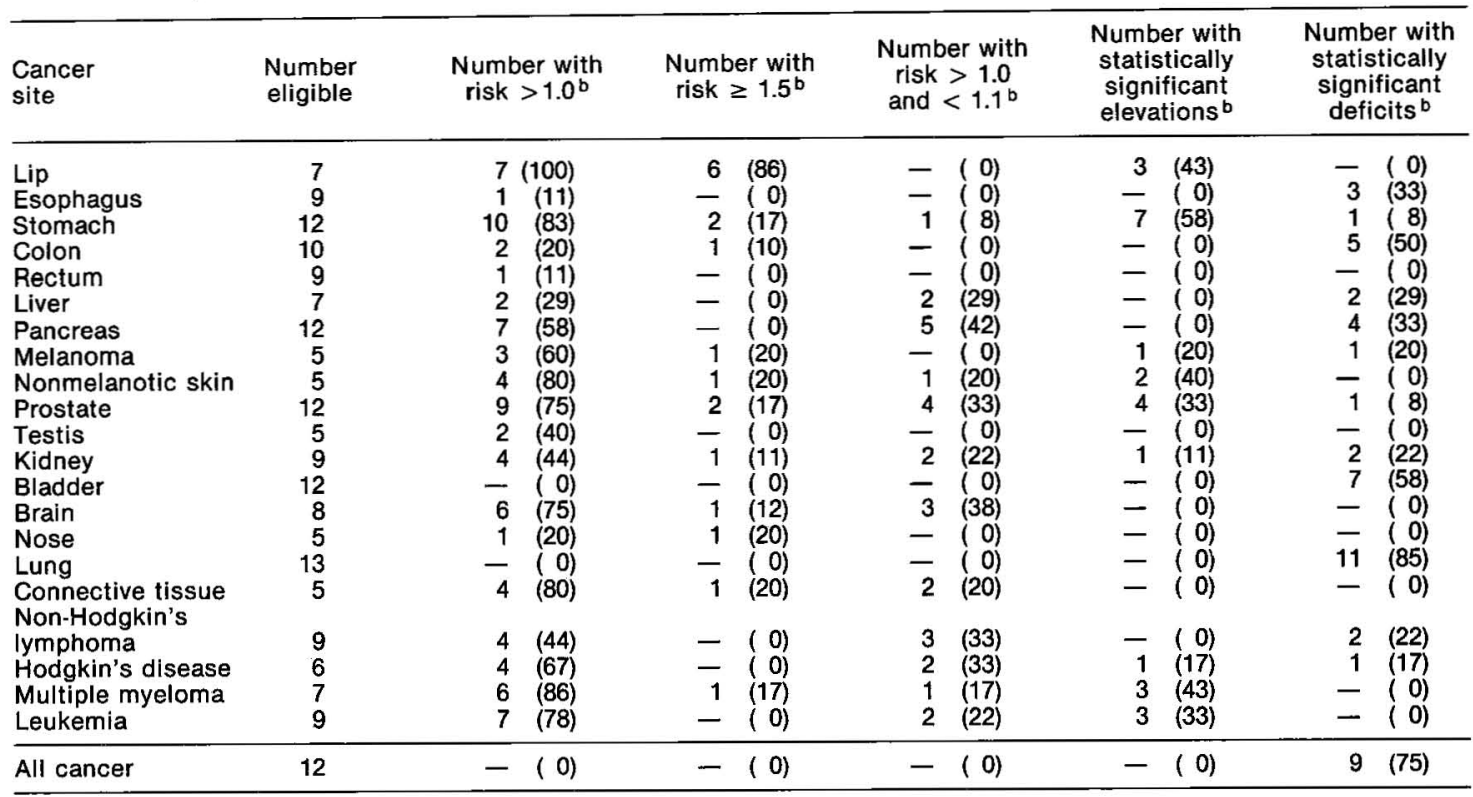

a Publications not providing number of cases not included.

b Percentage in parentheses.

of an increased risk of soft-tissue sarcoma among farmers and foresters with herbicide exposure are of particular interest $(33,46)$. The high proportionate mortality ratio for this cancer among Washington farmers (65) and the occurrence of soft-tissue sarcomas among industrial populations exposed to herbicides $(24,70,97)$ raise further concerns. However, in a New Zealand case-referent study of soft-tissue sarcomas, in which most of the exposed persons were farmers, the relative risk was elevated, but less than 2 (79). Reports are not yet available from ongoing casereferent studies of soft-tissue sarcoma in the United States that specifically focus on agricultural exposures.

\section{Lip cancer}

The excess risk of lip cancer among farmers in six surveys evaluating this site is consistent with the known association with outdoor occupations $(54,59,60)$. In one study of discharges from veteran's hospitals in the United States, $27 \%$ of the lip cancer patients, but only $8 \%$ of the referents, were farmers (54). Solar radiation is considered to play the major etiologic role in this excess.

\section{Nonmelanotic skin cancer}

As with cancer of the lip, excess mortality from nonmelanotic skin cancer among farmers $(16,26,48,65)$ is consistent with epidemiologic findings implicating ultraviolet radiation as the major etiologic factor (32, 36).

\section{Stomach cancer}

In addition to the surveys in tables 2-5, elevated mortality from stomach cancer among farmers has been reported in Kansas (49), Iowa (17), New York (56), and Ireland (78). In Iowa (17) farmers born before 1900 and residing in cattle- and corn-producing counties were at higher risk, while stomach cancer patients from the Roswell Memorial Park Institute showed an association with exposure to grain dusts (56). These findings may be confounded by social class since the risk of stomach cancer is inversely related to socioeconomic status (13). Diet is also thought to play a major role in the origin of stomach cancer, and studies indicate that a high intake of complex carbohydrates or salted food and a low intake of fresh fruits and vegetables are consistently related with high risk (69). This pattern closely parallels the diet of many nonmetropolitan families that emphasizes breads and potatoes rather than fresh fruit and vegetables (88).

There is also evidence that high nitrate intake, either from food or from water, is associated with stomach cancer. The problems caused by high nitrates are examined in detail in a report published by the National Academy of Sciences in the United States (71). Some salient facts from the report are as follows: (i) important sources of nitrates include leaching and surface runoff from croplands, (ii) agricultural watersheds have the highest nitrogen export rates, and (iii) fertilizer was the largest single anthropogenic input of fixed nitrogen into water in the contiguous United States in 1975. The two areas of highest use are the corn belt and the central valley of California. In addition several 
reports $(2,50,76,98)$ have concluded that positive correlations exist between stomach cancer and nitrates in drinking water and high consumption of salt-preserved foods, presumably high in nitrate and perhaps in sodium nitrite.

In addition nitrates may interact with common herbicides such as atrazine to produce n-nitrosamine, a known mutagen. Atrazine has a low basicity, and therefore the chemical environment of the stomach may offer a suitable site for n-nitrosamine formation from ingested atrazine in drinking water (95).

\section{Prostatic cancer}

Cancer of the prostate is associated with farming occupations in several of the large surveys of occupational groups $(16,26,65,94)$. The positive correlation between county mortality rates for prostatic cancer and chicken inventory (6) is consistent with the excess mortality noted among Washington poultrymen (65). A review of occupation and industry on death certificates from the Alameda and San Francisco counties in California indicated that gardeners and groundskeepers and persons in horticultural services (which included farmers) had elevated risks for prostate cancer (34). However, a case-referent interview study of prostate cancer in Minnesota did not find farmers to be at high risk (77). In Iowa (17) prostate cancer risk was greater among farmers born before 1900 and dying at older ages. This risk was not associated with any particular agricultural commodity, nor have other studies revealed compelling associations with specific agricultural agents.

\section{Brain cancer}

Mortality from cancer of the brain and central nervous system was elevated among farmers in Minnesota (23) and among Washington ranchers, dairymen, and poultrymen (65). Children from Maryland with brain cancer were more likely to have lived on farms than children without cancer (42). Previous contact with insecticides was more common among children with brain tumors than among reference children. These differences may be partially due to selective recall, since reported exposure to insecticides did not differ between children with brain cancer and children with other tumors. In an Italian study (67), glioma patients worked in agriculture more often than referents. This association was particularly evident among those first engaged in agricultural work after 1960 and those who worked for more than 10 years; these findings suggest that modern agricultural chemicals which became commonplace in the 1960s may be involved. A report of higher levels of organochlorine compounds in adipose tissue from glioblastoma patients than from noncancer referents (87) also supports the association between pesticides and brain cancer. Although the etiology of brain cancer is not well understood, these findings, plus reports of brain cancer among petruleum workers (86), suggest that exposure to certain chemicals may play a role.

\section{Studies of related occupations}

The mortality experience of veterinarians is of interest because of exposures they have in common with farmers, particularly to insecticides and zoonotic viruses. Elevated mortality from cancers of the lymphatic and hematopoietic system, brain and central nervous system, and skin (9) among veterinarians raises suspicion that exposures common to both groups may be involved. The increased relative frequency of skin cancer among veterinarians is confined to practitioners specializing in large animals, in accord with their presumed greater exposure to sunlight. Mortality from brain cancer was found to be excessive among all types of veterinarians (small animal, large animal) and nonpractitioners such as regulators and meat inspectors and is, therefore, not likely due to occupational exposures, but rather may reflect the quality of medical care received by professional groups. The leukemia excess is probably linked to $\mathrm{x}$-ray exposure, since the excess is mostly confined to veterinarians who practiced during the 1950s and 1960s, a period when there was rapid growth in diagnostic radiography without adequate attention to safety procedures (9). The role of zoonotic animal viruses in the origin of leukemia is possible, but unlikely, since we have no information to suggest that the level of contact of veterinarians with supposedly infectious animal agents has varied appreciably over the past several decades. In conclusion, although the cancer mortality pattern among veterinarians resembles that of farmers, it is unlikely that common environmental agents are involved, except for cancer of the skin.

Approximately $65 \%$ of all pesticides used in the United States in 1976 (74 \% of the herbicides, $59 \%$ of the insecticides, and $39 \%$ of the fungicides) were used by farmers (31). Twenty-five percent may have been applied by commercial applicators (52), who may have considerable contact with pesticides. Studies of pesticide applicators suggest that these workers may experience high risks for certain cancers, particularly cancer of the lung $(5,8)$, which is not excessive among farmers. Slight excesses of leukemia have also been reported among some pesticide-exposed populations $(8,27,83)$, but other studies have failed to uncover significant excesses $(66,91,92)$. None of the studies had the statistical sensitivity necessary to detect significant elevations in leukemia and other cancers less common than lung cancer.

\section{Discussion}

Epidemiologic studies suggest that farmers, despite their generally favorable overall mortality experience, have elevated risks for cancers of the lymphatic and hematopoietic system, stomach, prostate, brain, lip, 
skin, and connective tissue. The evidence is strongest for cancer of the lip, for which heavy exposure to ultraviolet radiation undoubtedly plays a predominant role. The epidemiologic evidence for an association between farming and lymphatic and hematopoietic tumors is intriguing. Potential biases related to diagnostic practices and the quality of medical care must, however, be considered for several of the cancers commonly high among farmers. Less sensitive diagnostic practices and a limited availability of medical care in rural areas may result in an underascertainment of leukemia and cancers of the brain and prostate. Such bias would, however, tend to understate the risk of these cancers among farmers. Although studies to evaluate the level of ascertainment among farmers apparently, have not been attempted, two recent investigations comparing characteristics of prostate cancer in Iowa farmers and nonfarmers have been completed An unpublished review of records of 800 histologically confirmed prostate cancer cases referred to University of Iowa hospitals between 1966 and 1978 indicated that the diagnosis of prostate cancer by a screening examination was less frequent for farmers $(4 \%, 9 \%$, $19 \%$ ) than for nonfarmers $(10 \%, 16 \%, 20 \%)$ among those aged $75,65-74$, and $50-64$ years, respectively. The stage of diagnosis was localized less among farmers for each of the three age groups. Although these results were not statistically significant within each age group, they do suggest that ascertainment is lower among farmers. Another study from the Iowa Health Registry (1971-1978) on stage of diagnosis of prostate cancer indicated that fewer farmers than nonfarmers were diagnosed at stage $\mathrm{I}$. The stage at diagnosis was localized in $64.3 \%$ of 1564 farmers, compared to $69.5 \%$ of 2693 nonfarmers. This difference is statistically significant $(\mathrm{p}<0.01)$.

Specific agents that might contribute to the excesses of certain cancers among farmers have yet to be identified. The identification of such agents is difficult because farm work involves exposure to a wide variety of potentially hazardous agents for which details on duration and intensity are generally unavailable. Epidemiolegic evidence for the role of oncogenic animal viruses is weak and consists primarily of sporadic reports of leukemia excesses among certain farm populations. No serologic evidence of human infection from such viruses has been found. Heavy pesticide use may account for some excess risk of cancer among farmers. The excess of leukemia among farmers suggests a link with pesticide exposure in view of the suggestion of an increased risk of leukemia among pesticide applicators and producers and case reports of pesticide-related aplasti. anemia and chromosome aberrations. Although certain chemicals associated with modern agriculture are suspect, analytic studies are now needed to clarify associations between farm work and particular cancers and to identify the specific etiologic agents. These studies should include an assessment of exposure through ambient air monitoring, patch tests for skin exposures and biochemical monitoring of levels of suspect agents or their metabolites in body fluids or tissues.

\section{References}

1. Agu AU, Christensen BL, Buffler PA. Geographic patterns of multiple myeloma: Racial and industrial correlates, state of Texas, 1969-71. J Natl Cancer Inst 65 (1980) 735-738.

2. Armijo R, Coulson AN. Epidemiology of stomach cancer in Chile: The role of nitrogen fertilizer. Int $\mathrm{J}$ Epidemiol 4 (1975) 301-309.

3. Axelson $O$. Aspects on confounding in occupational health epidemiology. Scand J Work Environ Health 4 (1978) 98-102.

4. Bailar JC, Ederer F. Significance factors for the ratio of a Poisson variable to its expectation. Biometrics 20 (1964) 639-643.

5. Barthel E. Increased risk of lung cancer in pesticide exposed male agricultural workers. J Toxicol Environ Health 8 (1981) $1027-1040$.

6. Blair A, Fraumeni JF Jr. Geographic patterns of prostate cancer in the United States. J Natl Cancer Inst 61 (1978) 1379-1384.

7. Blair A, Fraumeni JF Jr, Mason TJ. Geographic patterns of leukemia in the United States. J Chronic Dis 33 (1980) $521-526$.

8. Blair A, Grauman DJ, Fraumeni JF Jr, Lubin JH. Lung cancer and other causes of death among licensed pesticide applicators. J Natl Cancer Inst 71 (1983) $31-37$.

9. Blair A, Hayes HM Jr. Mortality patterns among US veterinarians, 1947-1977: An expanded study. Int J Epidemiol 11 (1982) 391-397.

10. Blair A, Thomas TL. Leukemia among Nebraska farmers: A death certificate study. Am J Epidemiol 110 (1979) 264-273.

11. Blair A, White DW. Death certificate study of leukemia among farmers from Wisconsin. J Natl Cancer Inst 66 (1981) $1027-1030$

12. Blair A, White D. Leukemia cell types and agricultural practices in Nebraska. Arch Environ Health (in press).

13. Buell P, Dunn JE, Breslow L. The occupational-social class risks of cancer mortality in men. J Chronic Dis 12 (1980) 600-621.

14. Buesching DP, Wollstadt L. Cancer among farmers. J Natl Cancer Inst 72 (1984) 503.

15. Burkart JA, Egleston CF, Voss RJ. The rural health study: Comparison of hospital experience between farmers and nonfarmers in a rural area of Minnesota. National Institute for Occupational and Safety, Cincinnati, $\mathrm{OH} 1978$.

16. Burmeister LF. Cancer mortality in Iowa farmers, 1971-1978. J Natl Cancer Inst 66 (1981) 461-464.

17. Burmeister LF, Everett GD, VanLier SF, Isacson P. Selected cancer mortality and farm practices in Iowa. Am J Epidemiol 118 (1983) 72-77.

18. Burmeister LF, VanLier SF, Isacson P. Leukemia and farm practices in Iowa. Am J Epidemiol 115 (1982) $720-728$

19. Cantor KP. Farming and mortality from non-Hodgkin's lymphoma: A case-control study. Int J Cancer 29 (1982) 239-247.

20. Cantor KP, Blair A. Farming and mortality from multiple myeloma: A case-control study with the use of death certificates. J Natl Cancer Inst 72 (1984) 251-255.

21. Cassel J, Heyden S, Bartel AG, Kaplan BH, Tyroler HA, Cornoni JC, Hames CG. Occupation and physical activity and coronary heart disease. Arch Intern Med 128 (1971) 920-928. 
22. Central Bureau of Statistics. Smoking habits in Sweden: A mail survey - Spring 1963. Stockholm 1965.

23. Choi NW, Schuman LM, Gullen WH. Epidemiology of primary central nervous system neoplasms: I Mortality from primary central nervous system neoplasms in Minnesota. Am J Epidemiol 91 (1970) 238-259.

24. Cook RR. Dioxin, chloroacne, and soft-tissue sarcoma. Lancet 1 (1981) 618-619.

25. Danmarks Statistik. Dodelighed og erhverv, 1970-75. Kobenhavn 1979. (Statistiske undersogelser $\mathrm{nr} 37$ ).

26. Decoufle P, Stanislawizyk K, Houten L, Bross IDJ, Viadana $\mathrm{E}$. A retrospective survey of cancer in relation to occupation. National Institute for Occupational Safety and Health. Cincinnati, OH 1977. (DHEW (NIOSH) publication no 77-178).

27. Ditraglia D, Brown DP, Namekata T, Iverson N. Mortality study of workers employed at organochlorine pesticide manufacturing plants. Scand J Work Environ Health 7 (1981): suppl 4, 140-146.

28. Donham KJ, Berg JW, Sawin RS. Epidemiologic relationships of the bovine population and human leukemia in Iowa. Am J Epidemiol 112 (1980) 80-92.

29. Donham KJ, VanDerMooten MJ, Miller JM, Kruse BC, Rubino MJ. Seroepidemiologic studies on the possible relationships of human and bovine leukemia: Brief communication. J Natl Cancer Inst 59 (1977) 851-853.

30. Dubrow R, Wegman DH. Occupational characteristics of cancer victims in Massachusetts 1971-1973. National Institute for Occupational Safety and Health, Cincinnati, OH 1984. (DHEW (NIOSH) publication no 84-109).

31. Eichers TR, Andrilenas PA, Anderson TW. Farmers' use of pesticides in 1976. US Department of Agriculture, Washington, DC 1978. (Agricultural economic report no 418).

32. Enamett EA. Ultraviolet radiation as a cause of skin tumors. CRC Crit Rev Toxicol 2 (1975) 211-255.

33. Eriksson M, Hardell L, Berg NO, Moller T, Axelson O. Soft-tissue sarcomas and exposure to chemical substances: A case-referent study. Br J Ind Med 38 (1981) 27-33.

34. Ernester VL, Selvin S, Brown SM, Sacks ST, Winkelstein W, Austin DF. Occupation and prostatic cancer. J Occup Med 21 (1979) 175—183.

35. Fasal E, Jackson EW, Klauber MR. Leukemia and lymphoma mortality and farmers' residence. Am J Epidemiol 87 (1968) 267-274.

36. Fears TR, Scotto J, Schneiderman MA. Mathematical models of age and ultraviolet effects on the incidence of skin cancer among whites in the United States. Am J Epidemiol 105 (1977) 420-427.

37. Ferrer JF, Kenyon SJ, Gupta P. Milk of dairy cows frequently contains a leukemia virus. Science 213 (1981) $1014-1016$.

38. Fox AJ, Goldblatt PO. Longitudinal study of sociodemographic mortality differentials, 1971-1975, Office of Population Censuses and Surveys. Her Majesty's Stationery Office, London 1980. (Series LS no 1).

39. Gallagher RP, Threlfall WJ, Jeffries E, Band PR, Spinelli J, Coldman AJ. Cancer and aplastic anemia in British Columbia farmers. J Natl Cancer Inst 72 (1984) 1311-1315.

40. Garabrant DH, Peters JM, Mack TM, Bernstein L. Job activity and colon cancer risks. Am J Epidemiol 119 (1984) 1005-1014.

41. Giles GG, Lickiss JN, Baikie MJ, Lowenthal RM, Panton J. Myeloproliferative and lymphoproliferative disorders in Tasmania, 1972-80: Occupational and familial aspects. J Natl Cancer Inst 72 (1984) 12331240.

42. Gold E, Gordis L, Tonascia J, Szklo M. Risk factors for brain tumors in children. Am J Epidemiol 109 (1979) $309-319$.
43. Guralnick L. Mortality by occupation and cause of death. Department of Health, Education and Welfare, Washington, DC 1963. (Vital statistics special report 53(3), DHEW (PHS)).

44. Gutensohn N, Cole P. Epidemiology of Hodgkin's disease. Semin Oncol 7 (1980) 92-102.

45. Hardell L, Eriksson M, Lenner P, Lundgren E. Malignant lymphoma and exposure to chemicals, especially organic solvents, chlorophenols, and phenoxy acids: A case-control study. Br J Cancer 43 (1981) 169-176.

46. Hardell L, Sandström A. Case-control study: Soft-tissue sarcomas. Br J Cancer 39 (1979) 711-717.

47. Heath CW, Caldwell GG, Feorino PC. Viruses and other microbes. In: Fraumeni JF Jr, ed. Persons at high risk of cancer, Academic Press, New York, NY 1975, pp 241-265.

48. Higginson CJ, Lee WR, Downes JE. Squamous cell skin cancer in the Northwest of England, 1967-69, and its relation to occupation. Br J Ind Med 36 (1979) 43-51.

49. Higginson J. Etiologic factors in gastrointestinal cancer in man. J Natl Cancer Inst 37 (1966) 527-545.

50. Hill MJ, Hawksworth G, Tattersoll G. Bacteria, nitrosamines, and cancer of the stomach. Br J Cancer 28 (1973) $562-567$.

51. Howe GR, Lindsay JP. A follow-up study of a tenpercent sample of the Canadian labor force: I Cancer mortality in males, 1965-73. J Natl Cancer Inst 70 (1983) $37-44$.

52. Jenkins R, Eichers TR, Andrilenas P, Fox A. Farmers' expenditures for custom pesticide services in 1964. US Department of Agriculture, Washington, DC 1968. (Agricultural economic report no 146).

53. Karlson $T$, Noren $T$. Farm tractor accidents: The failure of voluntary safety standards. Am J Public Health 69 (1979) $146-149$

54. Keller AZ. Cellular types, survival, race, nativity, occupation, habits and associated diseases in the pathogenesis of lip cancers. Am J Epidemiol 91 (1970) $486-499$.

55. Khoklova MD. Epidemiological studies of leukemias and lymphomas in the USSR. In: Levin DL, ed. Cancer epidemiology in the USA and USSR. National Institutes of Health, Bethesda, MD 1980, pp 229-233. (NIH publication no 80-2044).

56. Kraus AS, Levin ML, Gerhardt PR. A study of occupational associations with gastric cancer. Am J Public Health 47 (1957) 961-970.

57. Kvarnfors E, Henricson B, Hugoson GA. A statistical study on farm and village level on the possible relations between human leukemia and bovine leukosis. Acta Vet Scand 16 (1975) 163-169.

58. Lawhorne L. The health of farmers. J Iowa Med Soc 66 (1976) 409-418.

59. Lindquist C. Risk factors of lip cancer: A critical evaluation based on epidemiologic comparisons. Am J Public Health 69 (1979) 256-260.

60. Lindquist $\mathrm{C}$. Risk factors in lip cancer: A questionnaire study. Am J Epidemiol 109 (1979) 521-530.

61. Linos A, Kyle RA, Elveback LR, Kurland LT. Leukemia in Olmstead County, Minnesota, 1965-1974. Mayo Clin Proc 53 (1978) 714-718.

62. Linos A, Kyle RA, O'Fallon WM, Kurland LJ. A casecontrol study of occupational exposures and leukemia. Int J Epidemiol 9 (1980) 131-135.

63. McMichael AJ, Hartshorne JM. Mortality risks in Australian men by occupational groups, 1968-1978. Med J Aust 1 (1982) 253-256.

64. Milham S. Leukemia and multiple myeloma in farmers. Am J Epidemiol 94 (1971) 307-310.

65. Milham S Jr. Occupational mortality in Washington State, 1950-1979 National Institute for Occupational Safety and Health, Cincinnati, OH 1983. (DHHS publication no (NIOSH) 83-116). 
66. Morgan DP, Lin LI, Saikaly HH. Morbidity and mortality of workers occupationally exposed to pesticides. Arch Environ Contam Toxicol 9 (1980) 349-382.

67. Musicco M, Filippini G, Bordo BM, Mellotto A, Morello G, Berrino F. Gliomas and agricultural exposure to carcinogens: A case-control study. Am J Epidemiol 116 (1982) 782-790.

68. National Board of Occupational Safety and Health. Official statistics of Sweden, occupational injuries 1980. Stockholm 1983.

69. Nomura A. Stomach. In: Schottenfeld D, Fraumeni JF Jr, ed. Cancer epidemiology and prevention. WB Saunders Co, Philadelphia, PA 1982, pp 624-637.

70. Ott MG, Holder BB, Olson RD. A mortality analysis of employees engaged in the manufacture of $2,4,5-$ trichlorophenoxyacetic acid. J Occup Med 22 (1980) 47-50.

71. Panel on Nitrates of the Coordinating Committee for Scientific and Technical Assessments of Environmental Pollutants. Nitrates: An environmental assessment. National Academy of Sciences, Washington, DC 1978.

72. Pearce N, Smith A, Fisher D. Malignant lymphoma and multiple myeloma linked with agricultural occupations in New Zealand cancer registry-based study. Am J Epidemiol 121 (1985) 225-237.

73. Petersen GR, Milham S Jr. Occupational mortality in the state of California, 1959-1961. National Institute for Occupational Safety and Health, Rockville, MD 1980. (DHEW publication no (NIOSH, NIH) 80-104).

74. Pomrehn PR, Wallace RB, Burmeister LF. Ischemic heart disease mortality in Iowa farmers: The influence of lifestyle. J Am Med Assoc 284 (1982) 1073-1076.

75. Priester WA, Mason TJ. Human cancer mortality in relation to poultry population by county in 10 Southeastern states. J Natl Cancer Inst 53 (1979) 45-49.

76. Sato R, Fukuyoma T, Suguki T, Takayanogi J, Murakami T, Shiotsuhi N, Taraka R, Tsuji R. Studies of the causation of gastric cancer: The relation between gastric cancer mortality rate and salted food intake in several places in Japan. Bull Inst Public Health (Japan) 8 (1959) $187-198$.

77. Schuman LM, Mandel J, Blackard C, Bauer H, Scarlett J, McHugh R. Epidemiclogic study of prostatic cancer: Preliminary report. Cancer Treat Rep 61 (1977) $181-186$.

78. Siguyonsson $\mathrm{J}$. Occupational variations in mortality from gastric cancer in relation to dietary differences. $\mathrm{Br}$ J Cancer 21 (1967) 651-656.

79. Smith AH, Fisher DO, Giles HJ, Pearce N. The New Zealand soft tissue sarcoma case-control study: Interview findings concerning phenoxyacetic acid exposure. Chemosphere 12 (1983) 565-571.

80. Sordillo PP, Markovich RP, Hardy WD. Search for evidence of feline leukemia virus infection in humans with leukemia, lymphomas, or soft-tissue sarcomas. J Natl Cancer Inst 69 (1982) 333-337.

81. Stark A, Hoff M, Stone R. Cancer incidence and death from all causes in a cohort of farmers. Am J Epidemiol 118 (1983) 431.

82. Statistics Sweden. Dödsfalls registret 1961-1970. Stockholm 1981.

83. Stein WJ, Hayes WJ. Health survey of pest control operators. Ind Med Surg 33 (1964) 549-555.

84. Sterling TD, Weinkam JJ. Smoking characteristics by type of employment. J Occup Med 18 (1976) 743-754.

85. Surgeon General. Smoking and health - A report of the Surgeon General. Department of Health Education and Welfare, Washington, DC 1979. (DHEW publication no (PHS) 79-50066, USGPO).

86. Thomas TL, Waxweiler RJ, Moure-Eraso R, Itaya S, Fraumeni JF Jr. Mortality patterns among workers in three Texas oil refineries. J Occup Med 24 (1982) $135-141$.

87. Unger M, Olsen J. Organochlorine compounds in the adipose tissue of deceased patients with and without cancer. Environ Res 23 (1980) 257-263.

88. US Department of Agriculture. Food consumption: Households in the north central region, seasons and year 1977-78. US Government Printing Office, Washington, DC 1983. (Nationwide food consumption survey report no $\mathrm{H}-8)$.

89. Versluys JJ. Cancer and occupation in the Netherlands. Br J Cancer 3 (1949) 162-185.

90. Walrath J, Rogot E, Murray J, Blair A. Mortality patterns among US veterans by occupation and smoking status. US Government Printing Office, Washington, DC 1985. (NIH publication no 85-2756).

91. Wang HH, MacHan B. Mortality of workers employed in the manufacture of chlorane and heptachlor. J Occup Med 21 (1979) 745-748.

92. Wang $\mathrm{HH}$, MacMahon B. Mortality among pesticide applicators. J Occup Med 21 (1979) 741-744.

93. Wiklund K, Einhorn J, Wennström S, Rapaport E. A Swedish cancer-environment register available for research. Scand J Work Environ Health 7 (1981) 64-67.

94. Williams RR, Stegens NL, Goldsmith JR. Associations of cancer site and type with occupation and industry from the Third National Cancer Survey Interview. J Natl Cancer Inst 59 (1977) 1147-1185.

95. Wolf NL, Zepp RC, Gordon JA, Fincher RC. N-nitrosamine formation from atrazine. Bull Environ Contam Toxicol 15 (1959): 3, 342-347.

96. Wolska A. Human and bovine leukemias. Lancet 1 (1968) 1155

97. Zack JA, Suskind RR. The mortality experience of workers exposed to tetrachlorodibenzodioxin in a trichlorophenol accident. J Occup Med 22 (1980) 11-14.

98. Zaldiuav R, Wetterstand WH. Further evidence of a positive correlation between exposure to nitrate fertilizers $\left(\mathrm{NaNO}_{3}\right.$ and $\left.\mathrm{KNO}_{3}\right)$ and gastric cancer death rates: Nitrates and nitrosamines. Experientia 31 (1975) 13541355.

Received for publication: 16 April 1985 